\title{
The Effect of Cerebroside and Other Lipids on the Fixation of Tetanus Toxin by Gangliosides
}

\author{
By W. E. VAN HEYNINGEN AND JANE MELLANBY \\ Sir William Dunn School of Pathology, \\ University of Oxford
}

(Accepted for publication 22 February 1968)

\section{SUMMARY}

Water-insoluble complexes of ganglioside with cerebroside fixed tetanus toxin at low concentrations (a few LD $50 / \mathrm{ml}$.) of toxin. A complex containing $25 \%$ ganglioside with cerebroside was 50 times better at fixing toxin than complexes containing either $2 \%$ or $50 \%$ ganglioside. A complex containing $25 \%$ of a mixture of the gangliosides $\mathrm{G}_{\mathrm{III}}$ and $\mathrm{G}_{\mathrm{IV}}$ was $\mathrm{I} 2$ times better at fixing toxin than a similar complex with gangliosides $\mathrm{G}_{\mathrm{I}}$ and $\mathrm{G}_{\mathrm{II}}$. Complexes of ganglioside with sphingomyelin and lecithin fixed toxin to a slight extent, while complexes with tripalmitin and cholesterol did not fix toxin. The complex of cerebroside and ganglioside, containing $25 \%$ ganglioside, did not fix strychnine, serotonin, botulinum toxin or plasma albumin.

\section{INTRODUCTION}

Whole brain homogenate fixes tetanus toxin (Wassermann \& Takaki, 1898). The only purified components of nervous tissue which have been found to fix toxin are the gangliosides. This fixation has been demonstrated in the analytical ultracentrifuge where, at high concentrations of toxin $\left(5 \mathrm{mg} . / \mathrm{ml}\right.$, 30 million $\mathrm{LD}_{50} / \mathrm{ml}$.), ganglioside will fix up to 20 times its own weight of toxin (van Heyningen, 1963). The gangliosides are water-soluble but can be made insoluble by complexing them with other substances, such as cerebrosides, which are themselves insoluble in water. The cerebrosides do not fix tetanus toxin but their insoluble complexes with gangliosides do, and these can be used to study toxin fixation at low concentrations (a few LD 50/ml.) of toxin (van Heyningen, I959a, $b$; van Heyningen \& Miller, I96I). However, when the ability of nervous tissue to combine with toxin is compared with that of a complex containing equal parts of ganglioside and cerebroside, or with 'protagon' (a crude cerebroside preparation containing about $2.5 \%$ ganglioside; see van Heyningen, I $959 a, b)$, the toxin-fixing capacity apparently decreases with increasing ganglioside content of the preparations (Table 1 ). This would appear either to contradict the suggestion that the ability of nervous tissue to fix tetanus toxin is due to its content of ganglioside, or to suggest that some other component of nervous tissue (present also in 'protagon') takes part in the fixation of tetanus toxin by nervous tissue without necessarily being able to fix toxin by itself. In the present work, the fixation of tetanus toxin by complexes of gangliosides with water-insoluble lipids has been further investigated. A preliminary report of the conclusions of some of the work in this paper has appeared elsewhere (Mellanby \& van Heyingen, 1965). 


\section{METHODS}

Tetanus toxin was the preparation TD $464 \mathrm{D}$ kindly supplied by Dr R. O. Thomson of the Wellcome Research Laboratories; it contained $40 \%$ protein of which $75 \%$ was toxin (see van Heyningen, I959a,b). Dilutions of the toxin were made in 0.I Mphosphate buffer ( $\mathrm{pH} 7 \cdot 0$ ) containing $0.2 \%$ gelatin. Mixed gangliosides were prepared by the method described by Mellanby, Pope \& Ambache (1968). Crude cerebroside

Table I. Tetanus toxin fixing capacities of various preparations containing ganglioside

\begin{tabular}{|c|c|c|c|c|}
\hline \multirow[b]{2}{*}{ Preparation } & \multirow{2}{*}{$\begin{array}{c}\text { Ganglioside } \\
(\%)\end{array}$} & \multicolumn{2}{|c|}{$\begin{array}{l}\text { mg. required to fix } \\
\text { Io LD } 50 \text { of toxin }\end{array}$} & \multirow{2}{*}{$\begin{array}{c}\text { Relative } \\
\text { toxin-fixing } \\
\text { capacity per unit } \\
\text { ganglioside }\end{array}$} \\
\hline & & Total weight & Ganglioside & \\
\hline $\begin{array}{l}\text { Fresh guinea-pig brain } \\
\text { homogenate }\end{array}$ & 0.5 & 0.25 & 0.00125 & 800 \\
\hline 'Protagon' & $2 \cdot 5$ & 0.40 & $0.0 I$ & 100 \\
\hline $\begin{array}{l}\text { Ganglioside }+ \text { cerebroside } \\
\text { complex }\end{array}$ & 50 & 2 & I & $\mathbf{I}$ \\
\hline
\end{tabular}

(containing $0.75 \%$ ganglioside) was prepared by the method of Klenk \& Leupold (1944). Samples of highly purified cerebroside and sphingomyelin (containing no detectable ganglioside) were kindly provided by Professor H. E. Carter of the University of Illinois. Lecithin was obtained from British Drug Houses Ltd. (from egg: $95-100 \%$ ). The gangliosides $G_{I}, G_{I I}, G_{I I I}$ and $G_{I V}$ were kindly provided by the late Professor Richard Kuhn of Heidelberg. Total lipids of brain were prepared by homogenizing fresh guinea-pig brain with 30 volumes of chloroform + methanol $(2+1, v / v)$ and filtering off the residue. The filtrate was diluted one in four in the same solvent. This solution, representing $8 \mathrm{mg}$. fresh brain $/ \mathrm{ml}$., contained $0.8 \mathrm{mg}$. dry weight (i.e. total lipids)/ml. Strychnine and serotonin were obtained from British Drug Houses Ltd.

Sialic acid was estimated by the resorcinol method of Svennerholm (1957). Where the determination was to be made on mixtures of lipids, the gangliosides were first partially purified by adsorption on silicic acid followed by elution with methanol. The procedure used was adapted from a method devised by McCluer, Coram \& Lee (1962). An appropriate amount of the lipid extract in which the ganglioside was to be measured was evaporated to dryness and the lipids dissolved in I ml. methanol followed by $15 \mathrm{ml}$. chloroform. Silicic acid ( $1.5 \mathrm{~g}$.; previously washed in absolute methanol, $2 \mathrm{ml} . / \mathrm{g}$., and dried overnight at $70^{\circ}$ ) was weighed into a clean dry fritted glass funnel (porosity 2) and packed by gentle tapping. The silicic acid was wetted with 2-3 ml. chloroform + methanol $(\mathrm{I} 5+\mathrm{I}, \mathrm{v} / \mathrm{v})$ and the lipid solution was applied to it. The solvent was then forced through under positive pressure (rubber bulb) until the solvent was just level with the top of the silicic acid. The silicic acid was then washed in the same manner with $5 \mathrm{ml}$. chloroform + methanol $(9+\mathrm{I}, \mathrm{v} / \mathrm{v})$ followed by $5 \mathrm{ml}$. chloroform + -methanol $(3+\mathrm{I}, \mathrm{v} / \mathrm{v})$ and the washings discarded. The gangliosides were eluted from the column with two $5 \mathrm{ml}$. portions of absolute methanol, the second portion of methanol being forced through until the silicic acid was dry. The methanol eluate was evaporated to dryness in a stream of air in a water bath at $60^{\circ}$ and the residue was suspended in $2 \mathrm{ml}$. water (for the determination of sialic acid). 
Complexes of ganglioside with water-insoluble lipids were prepared by dissolving the two together in organic solvent, mixing, evaporating off the organic solvent and resuspending the residue in hot water (van Heyningen, 1963). When it was desired to add a constant amount of total brain lipid to decreasing amounts of ganglioside + cerebroside complex, the following procedure was used. The appropriate amounts of ganglioside and cerebroside were dissolved in chloroform + methanol $(\mathrm{I}+\mathrm{I}, \mathrm{v} / \mathrm{v})$ and serial 2 -fold dilutions of this solution were made with the same solvent. The appropriate volume of the chloroform + methanol extract of brain was then added to each of these dilutions, the solvent evaporated off, and the residues suspended in appropriate constant volumes of water.

Toxin-fixing capacity was measured by adding constant volumes of toxin solution (44 LD 50/ml.) to equal volumes of suspensions containing decreasing concentrations of nervous tissue or lipid complex, standing for 10 min., centrifuging at 20,000 rev./ min. for $15 \mathrm{~min}$. (40.2 head in Spinco Model L) and injecting $0.5 \mathrm{ml}$. volumes of the supernatant fluids intra-muscularly into pairs of mice. In this way the least amount of suspension required to fix $10 \mathrm{LD}_{50} \mathrm{doses}$ of toxin could be determined (van Heyningen, 1959 $b$ ).

\section{RESULTS}

To see whether a lipid component of brain was responsible for the superior toxinfixing ability per unit ganglioside of a brain homogenate compared with a cerebroside + ganglioside complex ( $50 \%$ ganglioside) the effect of the addition of the total lipids of a chloroform + methanol $(2+\mathrm{I}, \mathrm{v} / \mathrm{v})$ extract of brain on the toxin-fixing capacity of the complex was tested. The results of these tests are given in Table 2. It can be seen that the total brain lipids had comparatively low toxin-fixing capacity, but the addition of $0.8 \mathrm{mg}$. of these lipids to cerebroside + ganglioside (containing $50 \%$ ganglioside) increased the toxin-fixing capacity of the complex more than 90 -fold. Decreasing the ganglioside content of a complex to I0 $\%$ had a similar effect. However, addition of $0.8 \mathrm{mg}$. total brain lipids to this complex then decreased its toxin-fixing capacity 4-fold. A possible explanation of these apparently contradictory findings on the effect of brain extract on toxin fixation by cerebroside + ganglioside complexes was that the substance in brain extract enhancing toxin-fixation was cerebroside itself

Table 2. The effect of total brain lipids on the fixation of tetanus toxin by cerebroside: ganglioside complexes

\begin{tabular}{|c|c|}
\hline Lipids & $\begin{array}{l}\text { mg. required to fix } \\
\text { Io LD50 toxin }\end{array}$ \\
\hline Pure cerebroside & $5 \cdot 0$ \\
\hline Total brain lipids & $1 \cdot 6$ \\
\hline Crude cerebroside (containing $0.76 \%$ ganglioside) & 0.96 \\
\hline Crude cerebroside $+0.8 \mathrm{mg}$, total brain lipids & 0.85 \\
\hline $\begin{array}{l}\text { Crude cerebroside: ganglioside (containing } \\
50 \% \text { ganglioside) }\end{array}$ & I $\cdot 89$ \\
\hline $\begin{array}{l}\text { Crude cerebroside:ganglioside (containing } \\
50 \% \text { ganglioside) }+0.8 \mathrm{mg} \text {. total brain lipids }\end{array}$ & 0.02 \\
\hline $\begin{array}{l}\text { Crude cerebroside:ganglioside (containing } 10 \% \\
\text { ganglioside }\end{array}$ & 0.02 \\
\hline $\begin{array}{l}\text { Crude cerebroside:ganglioside (containing } 10 \% \\
\text { ganglioside) }+0.8 \mathrm{mg} \text {. total brain lipids }\end{array}$ & 0.08 \\
\hline
\end{tabular}


and that there is an optimal proportion of cerebroside in the complex-more than $50 \%$ but not much different from $90 \%$. Figure I shows the results of an experiment in which this possibility was tested. Complexes of ganglioside and cerebroside containing from $2 \%$ to $50 \%$ ganglioside were prepared and the weights of such complexes required to fix 10 LD 50 doses of tetanus toxin were determined. With a complex containing $25 \%$ ganglioside only one-fiftieth of the weight of the complex was required as compared with complexes containing either $50 \%$ or $2 \%$ gangliosides.

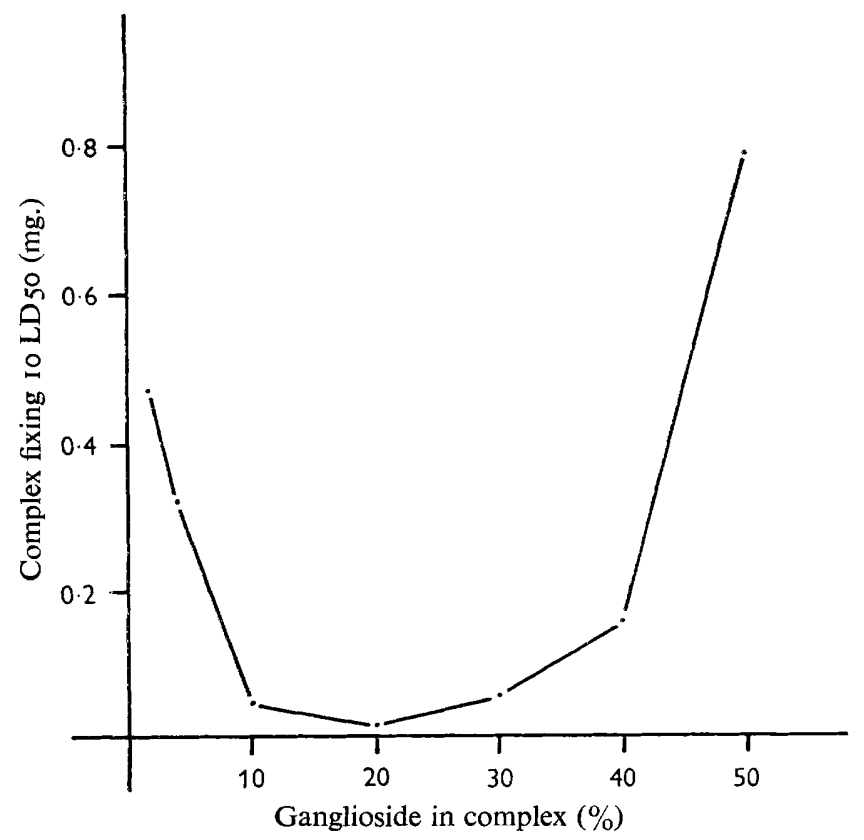

Fig. I. The effect of the proportion of ganglioside in a cerebroside + ganglioside complex on the toxin-fixing capacity of the complex.

Table 3. The toxin-fixing capacity of fresh guinea-pig brain and of a cerebroside: ganglioside complex, compared per unit dry weight and per unit ganglioside

\begin{tabular}{|c|c|c|c|c|c|}
\hline \multirow[b]{3}{*}{ Toxin sample } & \multicolumn{4}{|c|}{ Weight needed to fix $10 \mathrm{LD}_{50}$ of toxin } & \multirow{3}{*}{$\begin{array}{l}\text { Ratio of ganglioside } \\
\text { in complex to } \\
\text { ganglioside in brain } \\
\text { needed to fix } \\
\text { Io LD } 50 \text { of toxin } \\
\text { (col. } 5 / \text { col. } 4 \text { ) }\end{array}$} \\
\hline & \multicolumn{2}{|c|}{ mg. total weight } & \multicolumn{2}{|c|}{ mg. ganglioside } & \\
\hline & Brain & Complex* & Brain & Complex* & \\
\hline I & 0.59 & 0.07 & 0.002 & 0.02 & 10 \\
\hline 2 & 0.38 & 0.03 & 0.0019 & 0.008 & 4 \\
\hline 3 & 0.14 & $0.0 \mathrm{r}$ & 0.0007 & 0.0025 & 4 \\
\hline 4 & 0.09 & 0.008 & 0.00045 & 0.002 & 4 \\
\hline 5 & 0.6 & $0 \cdot 1$ & 0.003 & 0.024 & 8 \\
\hline
\end{tabular}

In Table 3 the results of five experiments are given in which the toxin-fixing capacity of brain homogenate and of the cerebroside + ganglioside complex containing $25 \%$ ganglioside are compared. In the fourth and fifth column of the table, the toxin-fixing 
capacity per unit of ganglioside is shown, and in the last column the ratio of these values is given. Although a 6-fold variability in the toxin-fixing capacity of brain and of the complex was found from experiment to experiment, the toxin-fixing capacity of brain expressed per unit ganglioside was consistently higher (4-to 10-fold) than that of the cerebroside + ganglioside complex.

Complexes of ganglioside with lipid components of brain other than cerebroside were also tested for their ability to fix tetanus toxin. Table 4 compares the ability to fix toxin of complexes containing $25 \%$ ganglioside with cerebroside, sphingomyelin, lecithin, cholesterol or tripalmitin. The complex with cerebroside was the most effective in toxin fixation, but the complexes with sphingomyelin and lecithin also had a little toxin-fixing capacity; the cholesterol and tripalmitin complexes did not fix toxin. The toxin-fixing capacity of ganglioside + sphingomyelin complexes was, like that of ganglioside + cerebroside complexes, greater when the proportion of ganglioside in the complex was $25 \%$, rather than $2 \%$ or $50 \%$.

Table 4. A comparison of the toxin-fixing capacity of complexes (containing $25 \%$ ganglioside) of ganglioside with different lipids

$\begin{array}{lc}\text { Second lipid } & \begin{array}{r}\text { mg. complex required } \\ \text { to fix } \text { ro LD50 }\end{array} \\ \text { Cerebroside } & 0.07 \\ \text { Cholesterol } & 8 \\ \text { Sphingomyelin } & 2.0 \\ \text { Lecithin } & 5.4 \\ \text { Tripalmitin } & >8\end{array}$

These results suggested that the receptor substance with which tetanus toxin combines, when it is fixed by nervous tissue, might include a complex of ganglioside and a water-insoluble component, probably cerebroside, containing about $25 \%$ of ganglioside. The question arose as to whether the combination of tetanus toxin at low toxin concentration (20 LD 50/ml.) with cerebroside + ganglioside complexes was an aspect of the same phenomenon as the fixation demonstrated in the ultracentrifuge at high toxin concentration ( $5 \mathrm{mg}$. toxin $/ \mathrm{ml}$; 30 million $\mathrm{LD} 50 / \mathrm{ml}$.). It had been shown in the ultracentrifuge that the ability of pure gangliosides to fix toxin depended upon the number and position of the sialic acid residues (van Heyningen, 1963). Complexes with cerebroside were therefore prepared containing $25 \%$ either of a mixture of gangliosides $G_{I}$ and $G_{I I}$, which were comparatively poor toxin-fixers in the ultracentrifuge, or of a mixture of gangliosides $G_{I I I}$ and $G_{I V}$, which were six times better. Table 5 shows that when their abilities to fix toxin at low toxin concentration were compared, the $\mathrm{G}_{I I I}+\mathrm{G}_{\mathrm{IV}}$ complex was twelve times as efficient as $\mathrm{G}_{\mathrm{I}}+\mathrm{G}_{\mathrm{II}}$.

It had also been shown previously, in the ultracentrifuge, that ganglioside alone would fix strychnine and serotonin (5-hydroxytryptamine) (van Heyningen, 1963). In contrast, however, it was found in the present work that a cerebroside + ganglioside complex which fixed tetanus toxin would not fix these substances. Like ganglioside alone, the complex would not fix botulinum toxin or plasma albumin. 
Table 5. Fixation of tetanus toxin by different gangliosides and by their complexes (containing $25 \%$ ganglioside) with cerebroside

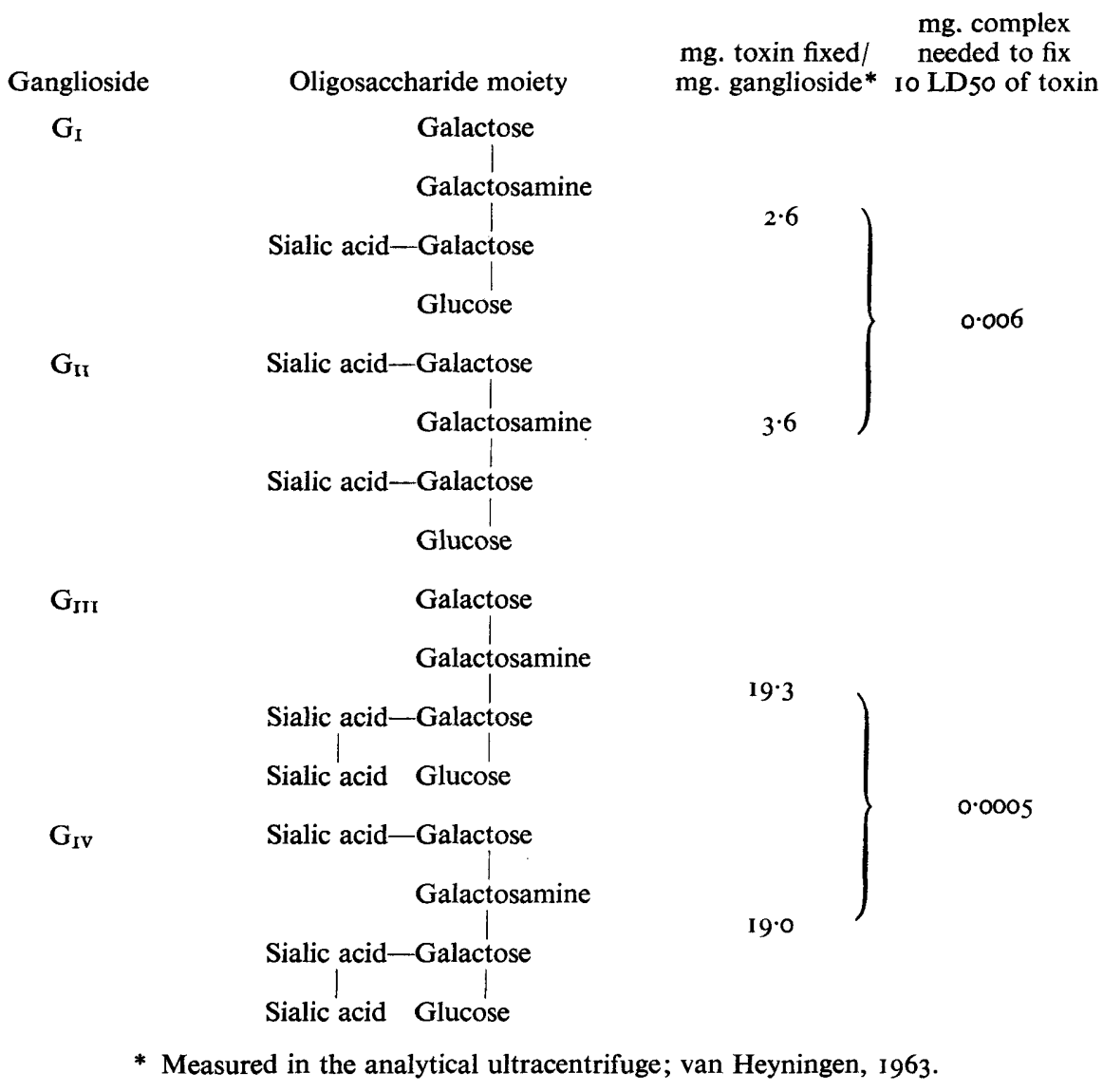

\section{DISCUSSION}

It has been found that the optimal proportion of ganglioside for toxin fixation in a ganglioside + cerebroside complex is about $25 \%$ ganglioside. The major part of both ganglioside and toxin-fixing capacity resides in the grey matter of brain. The proportions of ganglioside and cerebroside in grey matter are about equal. Thus if the receptor in nervous tissue for tetanus toxin includes such a complex of ganglioside and cerebroside (containing $25 \%$ ganglioside), only about one quarter of the ganglioside in grey matter can be involved.

Table 2 showed that it was not possible to account for more than $10-25 \%$ of the toxin-fixing capacity of brain per unit ganglioside on the assumption that the receptor for toxin is a complex of cerebroside and mixed gangliosides such as were used here. However, these gangliosides were extracted from dried brain with hot chloroform + methanol, $(2+I, v / v)$ and in these extracts the 'slow' gangliosides $\left(G_{\text {III }}, G_{\text {IV }}\right)$ comprised only about $10 \%$ of the total gangliosides. This is about a quarter of their proportion in the gangliosides in fresh brain (Suzuki, 1965). It has been shown in the 
present work that only about one-twelfth as much of a complex of cerebroside with $\mathrm{G}_{\mathrm{III}}$ and $\mathrm{G}_{\mathrm{IV}}$ gangliosides is needed to fix Io LD50 doses of tetanus toxin as is needed of a complex with $\mathrm{G}_{\mathrm{I}}$ and $\mathrm{G}_{\mathrm{II}}$ gangliosides. Hence, if a ganglioside + cerebroside complex were used in which the ganglioside contained the same proportion of $G_{I I I}$ and $G_{I V}$ as is present in brain, the toxin-fixing capacity per unit of ganglioside of the complex would be closer to that of brain. It is possible that the receptor substance for tetanus toxin in brain includes a cerebroside + ganglioside complex with other, nonlipid, constituents (perhaps histones; see van Heyningen, 1963).

It was previously shown that a major part of the toxin-fixing capacity of brain resides in the nerve endings (Mellanby, van Heyningen \& Whittaker, 1965) and within the nerve endings, it is the membranes rather than the mitochondria or the synaptic vesicles which fix the toxin (Mellanby \& Whittaker, 1968). It is possible that within the membrane fraction there is the optimal cerebroside + ganglioside ratio; but this need not be the case since there might of course only be small receptive areas on the membrane where the ratio is optimal, the ratio of cerebroside to ganglioside in the whole fraction not being optimal for fixation. For this reason it did not seem likely to be particularly fruitful to investigate the cerebroside:ganglioside ratios of subcellular fractions of the brain.

The fixation of tetanus toxin by high concentrations of gangliosides, as demonstrated in the ultracentrifuge, is fairly specific-none of the other enzymes, toxins or inert proteins that were tested were fixed except, to a far lesser extent, tetanus toxoid; but gangliosides also fix strychnine, bruceine, thebaine and serotonin under these conditions (van Heyningen, I963). If the fixation of tetanus toxin by mixed gangliosides were relevant to its mode of action, the fixation of these drugs, the first three of which have a physiological action comparable to that of tetanus toxin, might also be relevant to the biochemical action of tetanus toxin. However, it has been shown in the present work that strychnine and serotonin were not fixed by the cerebroside + ganglioside complex. It can therefore be seen that the fixation of tetanus toxin by cerebroside + ganglioside is more specific for tetanus toxin than is the fixation by ganglioside alone. The complex is therefore perhaps more likely than ganglioside alone to be included in the receptor for tetanus toxin in nervous tissue. The specificity of the combination between ganglioside and tetanus toxin with respect to the structure of the ganglioside is retained when the gangliosides are combined with cerebroside; the gangliosides which contain two sialic acid residues joined to each other are much better in fixation.

Van Heyningen \& Woodman (1963) showed that frog brain has a low toxin-fixing capacity compared with mammalian brain, and that frog brain ganglioside is extractable from the brain with water. The toxin-fixing capacity of frog brain ganglioside does not appear to differ from that of mammalian brain ganglioside. In mammalian brain the ganglioside is not extractable with water, and possibly is more firmly bound in water-insoluble complexes than frog brain ganglioside. This may be relevant to the relatively poor toxin-fixing capacity of frog brain.

Although this work may further have defined the receptor for tetanus toxin in nervous tissue and have shown it to be a more specific receptor for the toxin than ganglioside alone, it has not of course any further elucidated the role (if any) of ganglioside in the lethal action of tetanus toxin. 
We are grateful to Dr R. O. Thomson for providing the tetanus toxin; to Professor H. E. Carter and the late Professor Richard Kuhn for providing samples of cerebroside, sphingomyelin and gangliosides; to Mrs Diana Pope for skilled assistance. This work was done under contract (project no. 103-474) with the Office of Naval Research of the United States Department of the Navy.

\section{REFERENCES}

KLENK, E. \& LeUPOLD, F. (I944). Über eine vereinfachte Methode zur Darstellung von phosphorfreien Cerebrosiden und über die als Spaltprodukte auftretenden Fettsäuren. I8. Mitteilung über Cerebroside. Hoppe-Seylers Z. physiol. Chem. 281, 208.

MCCluer, R. H., Coram, E. H. \& LeE, H.S. (1962). A silicic acid adsorption method for the determination of ganglioside sialic acid. J. Lipid Res. 3, 269.

Mellanby, J., Pope, D. L. \& Ambache, N. (I968). The effect of the treatment of crude tetanus toxin with ganglioside cerebroside complex on sphincter paralytic action in the rabbit's eye. J.gen. Microbiol. 5o, 479 .

Mellanby, J. \& van Heyningen, W. E. (1965). The role of ganglioside in the mode of action of tetanus toxin. In Pharmacology of toxins, ed. H. Raudonat. Oxford, Pergamon Press.

Mellandy, J., van Heyningen, W. E. \& Whittaker, V. P. (I965). Fixation of tetanus toxin by subcellular fractions of brain. J. Neurochem. 12, 77.

Mellanby, J. \& WhitTaKer, V. P. (I968). The fixation of tetanus toxin by synaptic membranes. J. Neurochem. 15, 205.

SUZUKI, K. (I965). The pattern of mammalian brain gangliosides. II. Evaluation of the extraction procedures, post-mortem changes and the effect of formalin preservation. J. Neurochem. 12, 629 .

SVENNERHOLM, L. (I957). Quantitative estimation of sialic acids. II. A colorimetric resorcinol-hydrochloric acid method. Biochim. biophys. Acta 24, 604.

van Heyningen, W. E. (1959a). The fixation of tetanus toxin by nervous tissue. J. gen. Microbiol. 20, 291 .

van HeYNINGen, W. E. (1959b). Tentative identification of the tetanus toxin receptor in nervous tissue. J. gen. Microbiol. 20, 3 ro.

van Heyningen, W. E. (1963). The fixation of tetanus toxin, strychnine, serotonin and other substances by ganglioside. J. gen. Microbiol. 31, 375 .

van Heyningen, W. E. \& Miller, P. A. (196I). The fixation of tetanus toxin by ganglioside. J. gen. Microbiol. 24, 107.

van Heyningen, W. E. \& Woodman, R. J. (1963). The fixation of tetanus toxin by frog brain. J. gen. Microbiol. 31, 389.

WASSERMANN, H. \& TAKAKI, T. (1898). Über tetanusantitoxische Eigenschaften des normalen Zentralnervensystems. Berl. klin. Wschr. 35, 5. 